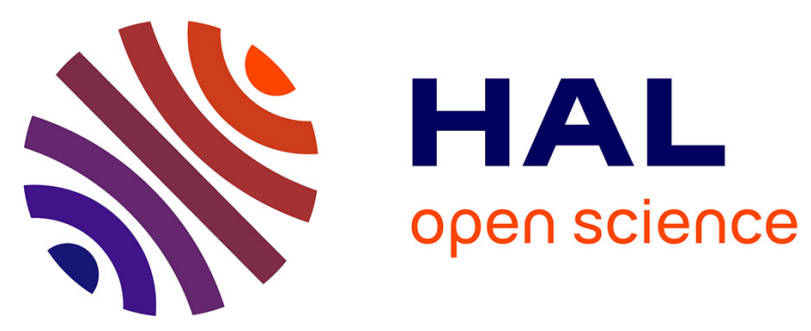

\title{
TRANSIENT ELASTOGRAPHY AND BIOMARKERS FOR LIVER FIBROSIS ASSESSMENT AND FOLLOW-UP OF INACTIVE HEPATITIS B CARRIERS
}

Laurent Castera, Pierre-Henri Bernard, Brigitte Lebail, Juliette Foucher, Pascale Trimoulet, Wassil Merrouche, Patrice Couzigou, Victor de Ledinghen

\section{To cite this version:}

Laurent Castera, Pierre-Henri Bernard, Brigitte Lebail, Juliette Foucher, Pascale Trimoulet, et al.. TRANSIENT ELASTOGRAPHY AND BIOMARKERS FOR LIVER FIBROSIS ASSESSMENT AND FOLLOW-UP OF INACTIVE HEPATITIS B CARRIERS. Alimentary Pharmacology and Therapeutics, 2010, 33 (4), pp.455. 10.1111/j.1365-2036.2010.04547.x . hal-00602613

\section{HAL Id: hal-00602613 https://hal.science/hal-00602613}

Submitted on 23 Jun 2011

HAL is a multi-disciplinary open access archive for the deposit and dissemination of scientific research documents, whether they are published or not. The documents may come from teaching and research institutions in France or abroad, or from public or private research centers.
L'archive ouverte pluridisciplinaire HAL, est destinée au dépôt et à la diffusion de documents scientifiques de niveau recherche, publiés ou non, émanant des établissements d'enseignement et de recherche français ou étrangers, des laboratoires publics ou privés. 


\begin{tabular}{l}
\hline Alimentary Pharmacology \\
\hline \& Therapeutics \\
\hline
\end{tabular}

\section{TRANSIENT ELASTOGRAPHY AND BIOMARKERS FOR LIVER FIBROSIS ASSESSMENT AND FOLLOW-UP OF INACTIVE HEPATITIS B CARRIERS}

\begin{tabular}{|r|l|}
\hline Journal: & Alimentary Pharmacology \& Therapeutics \\
\hline Manuscript ID: & APT-0748-2010.R1 \\
\hline Wiley - Manuscript type: & Original Scientific Paper \\
\hline Date Submitted by the & 24-Oct-2010 \\
\hline Complete List of Authors: & $\begin{array}{l}\text { Castera, Laurent; C.H.U Bordeaux, Hopital Haut Leveque, } \\
\text { Hepatogastroenterology } \\
\text { Bernard, Pierre-Henri; C.H.U. Bordeaux, Hopital St-Andre, } \\
\text { Hepatogastroenterology } \\
\text { LeBail, Brigitte; C.H.U Bordeaux, Hopital Pellegrin, Pathology } \\
\text { Foucher, Juliette; C.H.U. Bordeaux, Hopital haut Leveque, } \\
\text { Hepatogastroenterology } \\
\text { Trimoulet, Pascale; Chu bordeaux, Virology } \\
\text { Merrouche, wassil; CHU Bordeaux, hepatogastroenterology } \\
\text { Couzigou, Patrice; CHU Bordeaux, hepatogastroenterology } \\
\text { de ledinghen, Victor; Hopital Haut Leveque, C.H.U. Bordeaux, } \\
\text { Hepatogastroenterology }\end{array}$ \\
\hline Keywords: & $\begin{array}{l}\text { Hepatitis B < Hepatology, Liver fibrosis < Hepatology, Viral } \\
\text { hepatitis < Hepatology, Liver biopsy < Hepatology }\end{array}$ \\
\hline \hline
\end{tabular}

\section{SCHOLARONE Manuscripts}


TRANSIENT ELASTOGRAPHY AND BIOMARKERS FOR LIVER FIBROSIS ASSESSMENT AND FOLLOW-UP OF INACTIVE HEPATITIS B CARRIERS

Laurent Castéra (1, 2), Pierre-Henri Bernard (2), Brigitte Le Bail (3), Juliette Foucher (1, 2),

Pascale Trimoulet (4), Wassil Merrouche (1), Patrice Couzigou (1) and Victor de Lédinghen (1).

(1) Service d'Hépato-Gastroentérologie, Hôpital Haut-Lévêque, Centre Hospitalier Universitaire

(C.H.U.) Bordeaux, Pessac; France

(2) Service d'Hépato-Gastroentérologie, Hôpital St-André, C.H.U. Bordeaux, Bordeaux; France

(3) Service d'Anatomo-Pathologie, Hôpital Pellegrin, C.H.U. Bordeaux, Bordeaux; France

(4) Laboratoire de Virologie, Hôpital Pellegrin, C.H.U. Bordeaux, Bordeaux, France

\author{
Correspondence to: Laurent CASTERA, MD, PhD \\ Service d'Hépato-Gastroentérologie, \\ Hôpital Haut Lévêque, C.H.U. Bordeaux \\ Avenue Magellan, 33604 Pessac, France.
}

Tel: 0033557656439

Fax: 0033557656445

e-mail: laurent.castera@chu-bordeaux.fr 


\begin{abstract}
Aim

To evaluate longitudinally transient elastography (TE) and biomarkers for liver fibrosis assessment and follow-up of hepatitis B virus (HBV) inactive carriers.

\section{Methods}

Three hundred and twenty-nine consecutive HBeAg-negative HBV patients (201 inactive carriers) who underwent TE, Fibrotest ${ }^{\circledR}$ and APRI the same day were studied.

\title{
Results
}

TE (median 4.8 vs. $6.8 \mathrm{kPa}, \mathrm{p}<0.0001)$, Fibrotest@ $(0.16$ vs. $0.35, \mathrm{p}<0.0001)$ and APRI values ( 0.28 vs. $0.43, \mathrm{p}<0.0001)$ were significantly lower in inactive carriers than in the remaining patients whereas they did not differ between inactive carriers according to HBV DNA levels. In 82 inactive carriers with repeated examinations, although differences were observed among individual patients, TE values did not differ significantly over time (median intra-patient changes at end of follow-up relative to baseline: $-0.2 \mathrm{kPa}, \mathrm{p}=0.12$ ). Conversely, significant fluctuations were observed for Fibrotest $₫(+0.03, \mathrm{p}=0.012)$ and APRI $(-0.01, \mathrm{p}<0.05)$. Eleven inactive carriers $(5.5 \%)$ had initial elevated TE values $(>7.2 \mathrm{kPa})$ confirmed during follow-up in two with significant fibrosis (F2 and F3) on liver biopsy.

\section{Conclusions}

Non invasive tools, particularly transient elastography, could be useful, in addition to HBV DNA and transaminase levels, for follow-up of HBV inactive carriers as well as better selection of patients who require a liver biopsy. 


\section{INTRODUCTION}

Chronic hepatitis B virus (HBV) infection with negative Hepatitis B e antigen ( $\mathrm{HBe} A g)$ is becoming the predominant type of chronic HBV infection worldwide (1), as well as in France (2). The clinical spectrum of $\mathrm{HBeAg}$-negative chronic $\mathrm{HBV}$ infection may range from the inactive chronic HBsAg carrier state, characterized by persistently normal alanine aminotransferase (ALT) values, low or undetectable viremia and no liver injury to active chronic hepatitis B with elevated ALT activity, high HBV DNA levels, and active liver histological lesions. It is important and sometimes difficult to distinguish true inactive carriers (IC) from patients with active $\mathrm{HBeAg}$ negative chronic active hepatitis $\mathrm{B}(\mathrm{CHB})$ in whom phases of spontaneous remission may occur (3). IC have a good prognosis with a very low risk of complications and need just to be followed up regularly (1). Differential diagnosis with CHB is based largely on careful monitoring of ALT activity, serum HBV DNA levels, and liver histology. Although liver biopsy remains the reference method for assessment of liver disease severity in chronic HBV infection, it is currently not recommended in IC $(4,5)$. In addition, liver biopsy is a painful and invasive procedure $(6,7)$ with rare but potentially life-threatening complications $(8,9)$, and prone to sampling errors $(10$, 11). These limitations have stimulated the search for new non invasive approaches (12-14). A variety of methods including the measurement of liver stiffness, using transient elastography (TE) and biomarkers, ranging from routinely available non patented scores such as APRI to more complex patented algorithms such as the Fibrotest ${ }^{\circledR}$ (FT), have been proposed for the noninvasive assessment of hepatic fibrosis, mainly in chronic hepatitis C (15-20). Validation of these methods in hepatitis B is ongoing (21-24) but longitudinal data are still pending. The aim of this longitudinal study was to evaluate the value of TE and biomarkers (FT and APRI) for liver fibrosis assessment and follow-up of HBV inactive carriers. 


\section{PATIENTS \& METHODS}

\section{Patients}

Between June 2003 and June 2009, 412 patients were referred to our center for HBeAgnegative HBV-infection. The diagnosis of chronic HBV infection was based on the presence in serum of HBsAg and anti-HBe antibodies for greater than six months. Patients with other viral infection (HIV $(n=11), \operatorname{HCV}(n=7), \operatorname{HDV}(n=5))$, other causes of liver disease $(n=17)$, and unsuccessful liver stiffness measurements $(n=43)$ were excluded from the study. Finally, 329 patients were analyzed. Two hundred and one patients were considered as IC on the basis of persistently normal ALT and AST and HBV DNA $<10^{5}$ copies/ml $(<20000 \mathrm{IU} / \mathrm{ml})$ on at least 2 determinations during the past 6 months which corresponded to the IC definition when the study was initiated (25). The remaining patients $(n=128)$ were considered as HBeAg-negative chronic hepatitis (CHB). IC patients were also analyzed according to the new HBV DNA threshold of $2000 \mathrm{IU} / \mathrm{ml}$ proposed by EASL guidelines in 2009 (4).

All patients were enrolled after giving their written informed consent to the study which was approved by the Local Ethics Committee.

\section{Liver histology and staging of liver fibrosis}

Liver biopsy was performed according to clinical needs by senior operators using the Menghini technique with a 1.6-mm-diameter needle (Hepafix ${ }^{\circledR}$, Braun, Melsungen, Germany). Biopsy specimens were fixed in formalin and embedded in paraffin. All biopsy specimens were analyzed by the same trained pathologist blinded to the results of non invasive tests.

Liver fibrosis and necro-inflammatory activity were evaluated semi-quantitatively according to the METAVIR scoring system $(26,27)$. Fibrosis was staged on a 0-4 scale, as follows: F0, no 
fibrosis; F1, portal fibrosis without septa; F2, portal fibrosis and few septa; F3, numerous septa without cirrhosis; F4, cirrhosis. Activity was graded as follows: A0, none; A1, mild; A2, moderate; A3, severe.

Two clinically relevant end points were chosen: significant fibrosis ( $\mathrm{F} \geq 2)$ and cirrhosis ( $\mathrm{F} 4)$. The presence of significant fibrosis in HBV patients is considered a hallmark of a progressive liver disease and an indication for antiviral treatment and the presence of cirrhosis triggers screening for complications such as oesophageal varices and hepatocellular carcinoma (4)

\section{Liver stiffness measurement}

Liver stiffness measurements were performed using TE (FibroScan ${ }^{\circledR}$, Echosens, Paris, France). Details of the technical background and examination procedure have been previously described (28). Ten successful measurements were performed on each patient. The success rate was calculated as the number of validated measurements divided by the total number of measurements. The results were expressed in kilopascals $(\mathrm{kPa})$. The median value of successful measurements was considered representative of the liver stiffness in a given patient, according to the manufacturer's recommendations (interquartile range (IQR) less than $30 \%$ of the median value and success rate $>60 \%$ ). Unsuccessful results were defined as either failure (no valid measurement) or unreliable results (valid measurements $<10$ or success rate $<60 \%$ or interquartile range (IQR) $>30 \%$ of median value) (29). The cut-offs used for diagnosing significant fibrosis and cirrhosis were those proposed by Marcellin et al. (21) in French patients $(7.2 \mathrm{kPa}$ and 11.0 $\mathrm{kPa}$, respectively).

Liver stiffness measurements were repeated over time (every 6 to 12 months) since 2005 in IC patients, particularly in those with initial elevated liver stiffness values $(>7.2 \mathrm{kPa})$. In case of elevated liver stiffness values on at least two examinations, a liver biopsy was proposed. 
Castéra et al.

\section{Serum biomarkers}

The parameters allowing the calculation of FT and APRI were determined in the same laboratory on blood sampled at the time of TE. The FT score was purchased from Biopredicitve website (www.biopredictive.com). The APRI was calculated according to the original formula as follows: AST levels divided by its upper normal limit / platelet count (10\%/L) x 100 (18). The cutoffs used for diagnosing significant fibrosis and cirrhosis were those from original publications: FT values $>0.48$ and $>0.74$, respectively (19); APRI values $<0.5$ or $\geq 1.5$ and $<1$ or $\geq 2$, respectively (18).

\section{Statistical analysis}

Patient characteristics are given as mean \pm SD or as median and range as appropriate. Comparisons between groups were performed using nonparametric tests, including the Mann and Whitney test ( 2 groups) or the Kruskal-Wallis test (3 groups). Comparisons between groups for qualitative data were performed using Chi-square test or Fisher's exact test when necessary. Intragroup comparisons were made using Wilcoxon's test for paired data. Tests were two-tailed and pvalues $<0.05$ were considered significant.

Receiver operating characteristics (ROC) curves were constructed. Sensitivity (Se), specificity (Sp), positive and negative predictive values (PPV and NPV), positive likelihood ratio (+LR) and negative likelihood ratio (-LR) were calculated using cut-offs previously described for significant fibrosis and cirrhosis for TE, FT and APRI. Also for TE, cut-offs were established in our population according to ROC curve in order to maximize Se and $\mathrm{Sp}$. Areas under ROC curve (AUROC) were calculated using the trapezoidal rule. Comparisons of AUROCs were done using the method described by Hanley and McNeil for correlated data (30). Initially, we compared all AUROCs, and in case of rejection of the null hypothesis (all AUROCs are equal), differences 
Castéra et al.

were searched for by two-by-two comparisons, using Bonferroni adjustement for multiple pairwise comparisons. Analyses were performed using SPSS software (Statistical Systems, Kayville, UT) and Stata V8.0 (StataCorp 2003. Stata Statistical Software: release 8.0. College Station, TX). 
Castéra et al.

\section{RESULTS}

\section{Patients}

The baseline characteristics of the 329 patients are shown in table 1 . There were 205 men (62\%), and their mean age was $39 \pm 14$ years. Among these patients, 60 underwent a liver biopsy. The mean liver biopsy length was $22.6 \pm 8.0 \mathrm{~mm}$. As expected, IC were significantly younger (36 \pm 12 vs. $44 \pm 16$ yrs, respectively, $\mathrm{p}<0.0001$ ), were less often male (54\% vs. $76 \%$, respectively, $\mathrm{p}<0.0001)$, and had lower HBV DNA $\left(1.5 \pm 2.710^{3}\right.$ vs. $7.4 \pm 27.910^{6} \mathrm{IU} / \mathrm{L}$, respectively, $\left.\mathrm{p}=0.0002\right)$ than $\mathrm{CHB}$ patients.

\section{Cross-sectional study \\ Comparative diagnostic performance of TE and biomarkers for fibrosis staging}

In the 60 patients who underwent a liver biopsy, activity grade and fibrosis score were as follows: A0-A1 (n=25); A2 (n=22); A3 (n=13) and F0-F1 $(n=16) ; F 2(n=16) ; F 3(n=13) ; F 4$ $(n=15)$. Diagnostic performances of TE and biomarkers are shown in Table 2.

TE, FT and APRI had similar performance for F $\geq 2$ (AUROC (95\% CI): 0.76 (0.63-0.90), 0.71 (0.58-0.85), and $0.66(0.50-0.82)$, respectively, $\mathrm{p}=\mathrm{NS})$. Conversely, for F4 TE had better performance than FT $(0.89(0.80-0.98)$ vs. $0.74(0.58-0.90)$, respectively, $\mathrm{p}=0.03)$ but not different from APRI (0.89 (0.80-0.98) vs. $0.79(0.67-0.91)$, respectively, $\mathrm{p}=\mathrm{NS})$. The TE cut-offs optimized in our population were: $7.1 \mathrm{kPa}$ for significant fibrosis $(\mathrm{F} \geq 2)$ and $9.6 \mathrm{kPa}$ for cirrhosis (F4), respectively.

\section{Comparison of TE and biomarkers between inactive carriers and HBeAg-negative disease}

IC had significantly lower liver stiffness values (median: 4.8 (4.1 - 5.8) vs. 6.8 (4.9 - 9.5) kPa, respectively; p<0.0001), FT values (median: 0.16 (0.10 - 0.25) vs. 0.35 (0.19 - 0.60), respectively; 
$\mathrm{p}<0.0001)$ and APRI values (median: 0.28 (0.22 - 0.35) vs. 0.43 (0.29 - 0.72), respectively; $\mathrm{p}<0.0001$ ) than CHB patients (Figure 1).

Interestingly, eleven IC (5.5\%) had elevated liver stiffness values $(\geq 7.2 \mathrm{kPa})$ suggestive of significant fibrosis (Table 3). All were offered follow-up and their characteristics are detailed below in the longitudinal study chapter.

\section{Comparison of TE and biomarkers according to HBV DNA levels in inactive carriers}

The distribution of serum HBV DNA levels among IC was as follows: undetectable $(<12$ IU/mL), 33 (16\%); $12<<2000 \mathrm{IU} / \mathrm{mL}, 139$ (65\%); and $2000<<20000 \mathrm{IU} / \mathrm{mL}, 39(19 \%)$. Patients with HBV DNA levels $<2000 \mathrm{IU} / \mathrm{mL}(81 \%)$ correspond to the recently proposed EASL definition for IC (4) whereas patients with HBV DNA levels $<20000 \mathrm{IU} / \mathrm{mL}$ correspond to the classical definition (25). IC did not differ according to serum HBV DNA levels for baseline characteristics (age, gender, BMI, ALT and AST) as well as for liver stiffness values, FT and APRI values (Figure 2).

\section{Longitudinal study}

Among the 201 IC, 82 underwent repeated TE and biomarkers determinations: 2 determinations $(\mathrm{n}=82)$ (median interval of 11.5 months; range: $3.3-26.8)$; 3 determinations $(\mathrm{n}=48)$ (median 23.1 months; range: 10.1-34.7), and 4 determinations ( $\mathrm{n}=27$ ) (median 34.4 months; range: 21.6-49.1). When pooling the different time points for the 82 patients, taking into account the last available time point (end of follow-up), the median interval was: 21.7 months (range: 3.349.1). These 82 patients did not differ from the other IC for baseline characteristics (age, gender, BMI, ALT, AST, platelet count), FT and APRI except for liver stiffness values (median 5.0 vs. 4.6 $\mathrm{kPa}$, respectively, $\mathrm{p}=0.005)$. Indeed, as mentioned before, eleven of these patients had liver 
stiffness values $>7.2 \mathrm{kPa}$ at first examination, suggestive of the presence of significant fibrosis. Their characteristics are detailed in Table 3. These patients did not differ from the other 190 IC for most baseline characteristics (age, gender, BMI, ALT, AST, and platelet count), FT and APRI, and TE success rate, except for the IQR/median value ratio (mean $0.21 \pm 0.08$ vs. $0.16 \pm 0.07$, respectively, $\mathrm{p}<0.03$ ). During follow-up, liver stiffness values returned to values below $7.2 \mathrm{kPa}$ in all patients except two. These two patients (number 1 and 6) underwent liver biopsy. Patient number 1 had moderate fibrosis (F2) whereas patient number 6 had severe fibrosis (F3). Both were offered antiviral treatment.

Table 4 shows the median intra-patient changes in liver stiffness, FT, APRI, AST, ALT and HBV DNA values at different time points relative to baseline in the 82 IC patients who underwent at least 2 determinations of non invasive methods over time. Globally, the liver stiffness changes observed in 82 patients at the end of follow-up (last determination available) relative to baseline were not significant, although there was a trend toward a decrease in liver stiffness over time (median intra-patient changes at end of follow-up: $-0.2(-1.2-+0.7) \mathrm{kPa}$, $\mathrm{p}=0.12$ ). As shown in Figure $3 \mathrm{~A}$, there were differences among individual patients, however, the median intra-patient liver stiffness changes relative to baseline were not significant: $+0.1(-0.9$ $+0.5) \mathrm{kPa}(\mathrm{p}=0.41)$ at $2^{\text {nd }}$ determination and $-0.1(-0.9-+0.5) \mathrm{kPa}(\mathrm{p}=0.33)$ at $3^{\text {rd }}$ determination (Table 4). Similarly, no significant change was observed for AST, ALT and HBV DNA levels at the end of follow-up relative to baseline (Table 3 ).

Conversely, a significant increase in FT values was observed over time: median of intrapatient changes in FT values at the end of follow-up relative to baseline $(+0.03(-0.04-+0.09)$, $\mathrm{p}=0.012$ ) (Table 4). Patients had significantly higher values at the end of follow-up than at baseline (median $0.19(0.12-0.32)$ vs. $(0.16(0.10-0.24) \mathrm{p}=0.012)$. Five patients $(6 \%)$ had at baseline FT values suggestive of significant fibrosis $(>0.48)$ but none of cirrhosis $(>0.74)$. During 
follow-up, FT values remained comprised between 0.48 and 0.74 in these 5 patients. As shown in Figure 3B, there were important differences among individual patients and FT values fluctuated over time: as a result, median intra-patient FT changes relative to baseline were significant: +0.03 $(-0.03-+0.07)(\mathrm{p}=0.03)$ at $2^{\text {nd }}$ determination and $+0.05(-0.03-+0.11)(\mathrm{p}=0.001)$ at $3^{\mathrm{rd}}$ determination (Table 4).

As for APRI, there were also differences among individual patients and APRI values fluctuated over time (Figure 3C). A significant decrease was observed over time: median of intrapatient changes at the end of follow-up relative to baseline $(-0.01(-0.07-+0.03), \mathrm{p}<0.05)($ Table 4). 


\section{DISCUSSION}

The results of the present study, based on a large series of consecutive HBeAg-negative HBV patients, suggest that non invasive tools for liver fibrosis assessment, particularly TE, may be useful for liver fibrosis assessment and follow-up of IC.

Among the different available non invasive methods, we chose to evaluate two different and complementary approaches: i) a physical approach based on the measurement of liver stiffness using TE; ii) a biological approach based on serum biomarkers including a patented algorithm (FT) and a free non patented index (APRI) (31). These three non invasive methods are by far the most widely used and validated (32-34).

In the cross-sectional part of the study, we first validated the performances of TE, FT and APRI against liver biopsy for diagnosing significant fibrosis and cirrhosis in our population. TE had better diagnostic accuracy for cirrhosis (AUROC 0.89) than for significant fibrosis (0.76), as previously reported in hepatitis $\mathrm{C}(32)$ and hepatitis $\mathrm{B}(21,35,36)$. Interestingly, the TE cut-off we found for significant fibrosis $(7.1 \mathrm{kPa})$ is similar to the one we proposed initially in chronic hepatitis C (16) and close to those recently proposed in chronic hepatitis B by Marcellin et al. (7.2 $\mathrm{kPa})(21)$, as well as other groups $(35,36)$. As for cirrhosis, our cut-off $(9.6 \mathrm{kPa})$ is lower than in hepatitis $\mathrm{C}(12.5 \mathrm{kPa})(16)$ but close to those proposed in hepatitis $\mathrm{B}(21,23,35,36)$. The higher prevalence of macronodular cirrhosis in chronic hepatitis $\mathrm{B}$ than in hepatitis $\mathrm{C}$ as well as differences in the prevalence of cirrhosis in the different studied populations may account for these differences. As for FT and APRI, their performances were in keeping with those previously reported in hepatitis B $(24,37-39)$. Interestingly, although performance did not differ between the three methods for the diagnostic of significant fibrosis, TE had better diagnostic accuracy than FT for cirrhosis, a finding consistent with our experience in patients with chronic hepatitis $\mathrm{C}$ (40). $\underline{\text { In }}$ 
that respect, some authors have proposed algorithms combining TE with serum biomarkers to increase diagnostic accuracy for advanced fibrosis in patients with chronic hepatitis B (41).

Although liver biopsy remains important for determining active disease (42), it is not feasible or necessary to biopsy all HBeAg-negative patients with near normal ALT and relatively low HBV DNA levels (43). Non invasive tests could provide an additional adjunct for separating patients with inactive and minimal fibrosis from those for whom a liver biopsy could be mandated. Liver stiffness values in our series of 201 IC were low and similar to those reported in two recent series of healthy individuals with (44) and without (45) liver biopsy as well as in patients with chronic hepatitis C and persistently normal ALT (46). In addition, liver stiffness values were significantly lower than in $\mathrm{CHB}$ patients and consistent with those previously reported in IC $(36,47)$. However, no serum fibrosis biomarker was evaluated in these two studies $(36,47)$. Interestingly, both APRI and FT values were low in our IC as previously reported (38) and significantly lower than in CHB patients.

As a new definition of IC has been recently proposed (4), we also examined the results of non invasive tests according to HBV DNA levels. Approximately $80 \%$ of our IC patients had HBV DNA levels $<2000 \mathrm{IU} / \mathrm{ml}$, corresponding to this new definition, a finding in keeping with those of a recent series of 85 IC where $23 \%$ of patients had HBV DNA $<2000 \mathrm{IU} / \mathrm{mL}$ (48). Interestingly, TE, FT and APRI values did not differ according to HBV DNA levels in IC whereas they were significantly higher in patients with HBV DNA >20 $000 \mathrm{IU} / \mathrm{mL}$. Such findings are consistent with those of Papatheodoridis et al. (43) showing that in patients with persistently normal ALT and HBV DNA <20 000 IU/L, the 2000 IU/L cut-off does not allow discriminating between patients with and without significant fibrosis on liver biopsy.

In the second longitudinal part of the study, we thoroughly evaluated the evolution of TE, FT and APRI over time by measuring median intra-patients changes at different time points relative 
to baseline in 82 IC with repeated examinations (2 to 4 examinations). Interestingly, although some differences were observed among individual patients (Figure 3), liver stiffness values were stable over time, as were AST, ALT and HBV DNA levels. Conversely, significant fluctuations were observed with FT and APRI.

We have no clear explanation for this latter finding. In the only study were FT was assessed longitudinally in 160 IC (38), reproducibility was deemed excellent but no data were provided regarding the median or mean FT values over time. It is possible that some components of FT such as bilirubin levels or apha2-macroglobulin may fluctuate over time (49). Similarly with APRI, AST and platelet may fluctuate over time. Concerning TE, it has been shown to be highly reproducible (50) and fluctuations of liver stiffness over time are mainly related to acute inflammation or ALT flares $(22,36,51)$, which are usually not observed in IC.

Interestingly, eleven out of 201 IC $(5.5 \%)$ had baseline elevated liver stiffness values (> 7.2 $\mathrm{kPa}$ ), suggestive of the presence of significant fibrosis. During follow-up, liver stiffness values returned to values below $7.2 \mathrm{kPa}$ in all patients but two. It should be noted that when compared to the other IC, these 11 patients had significantly higher TE IQR/median value ratio. The importance of this ratio for accuracy of TE results has been recently emphasized (52). This finding suggests that when liver stiffness values are elevated $(>7.2 \mathrm{kPa})$ in patients with a profile of IC, TE should be repeated before taking a liver biopsy, to make sure that IQR/median value ratio is satisfactory. Indeed, in the two patients with baseline elevated liver stiffness values confirmed on a second examination, liver biopsy revealed the presence of significant fibrosis in both cases (F2 and F3), suggesting that TE in this context is a sensitive tool for detection of significant fibrosis.

In conclusion, our results suggest that non invasive tools for liver fibrosis assessment, particularly transient elastography, could be useful, in addition to HBV DNA and transaminase 
levels, for follow-up of HBV inactive carriers as well as better selection of patients who require a liver biopsy.

\section{Acknowledgments:}

We are grateful to Dr Françoise Roudot-Thoraval for her helpful statistical comments on the manuscript.

Conflicts of interest: nothing to disclose

Financial support: none 


\section{REFERENCES}

1. Dienstag JL. Hepatitis B virus infection. N Engl J Med 2008;359:1486-500.

2. Zarski JP, Marcellin P, Leroy V, et al. Characteristics of patients with chronic hepatitis B in France: predominant frequency of HBe antigen negative cases. J Hepatol 2006;45:355-60.

3. Brunetto MR, Oliveri F, Coco B, et al. Outcome of anti-HBe positive chronic hepatitis B in alpha-interferon treated and untreated patients: a long term cohort study. J Hepatol 2002;36:263-70.

4. European Association For The Study Of The Liver. EASL Clinical Practice Guidelines: management of chronic hepatitis B. J Hepatol 2009;50:227-42.

5. Lok AS, McMahon BJ. Chronic hepatitis B: update 2009. Hepatology 2009;50:661-2.

6. Castera L, Negre I, Samii K, et al. Pain experienced during percutaneous liver biopsy. Hepatology 1999;30:1529-30.

7. Castera L, Negre I, Samii K, et al. Patient-administered nitrous oxide/oxygen inhalation provides safe and effective analgesia for percutaneous liver biopsy: a randomized placebocontrolled trial. Am J Gastroenterol 2001;96:1553-7.

8. Cadranel JF, Rufat P, Degos F. Practices of liver biopsy in France: results of a prospective nationwide survey. For the Group of Epidemiology of the French Association for the Study of the Liver (AFEF). Hepatology 2000;32:477-81.

9. Piccinino F, Sagnelli E, Pasquale G, et al. Complications following percutaneous liver biopsy. A multicentre retrospective study on 68,276 biopsies. J Hepatol 1986;2:165-73.

10. Bedossa P, Dargère D, Paradis V. Sampling variability of liver fibrosis in chronic hepatitis C. Hepatology 2003;38:1449-57.

11. Regev A, Berho M, Jeffers LJ, et al. Sampling error and intraobserver variation in liver biopsy in patients with chronic HCV infection. Am J Gastroenterol 2002;97:2614-8. 
12. Castera L. Transient elastography and other noninvasive tests to assess hepatic fibrosis in patients with viral hepatitis. J Viral Hepat 2009;16:300-314.

13. Pinzani M, Vizzutti F, Arena U, et al. Technology Insight: noninvasive assessment of liver fibrosis by biochemical scores and elastography. Nat Clin Pract Gastroenterol Hepatol 2008;5:95-106.

14. Castera L, Pinzani M. Non-invasive assessment of liver fibrosis: are we ready? Lancet 2010;375:1419-20.

15. Sandrin L, Fourquet B, Hasquenoph JM, et al. Transient elastography: a new noninvasive method for assessment of hepatic fibrosis. Ultrasound Med Biol 2003;29:1705-13.

16. Castera L, Vergniol J, Foucher J, et al. Prospective comparison of transient elastography, Fibrotest, APRI, and liver biopsy for the assessment of fibrosis in chronic hepatitis C. Gastroenterology 2005;128:343-50.

17. Ziol M, Handra-Luca A, Kettaneh A, et al. Noninvasive assessment of liver fibrosis by measurement of stiffness in patients with chronic hepatitis C. Hepatology 2005;41:48-54.

18. Wai CT, Greenson JK, Fontana RJ, et al. A simple noninvasive index can predict both significant fibrosis and cirrhosis in patients with chronic hepatitis C. Hepatology 2003;38:518-26.

19. Imbert-Bismut F, Ratziu V, Pieroni L, et al. Biochemical markers of liver fibrosis in patients with hepatitis C virus infection: a prospective study. Lancet 2001;357:1069-75.

20. Castera L, Denis J, Babany G, et al. Evolving practices of non-invasive markers of liver fibrosis in patients with chronic hepatitis C in France: Time for new guidelines? J Hepatol 2007;46:528-529.

21. Marcellin P, Ziol M, Bedossa P, et al. Non-invasive assessment of liver fibrosis by stiffness measurement in patients with chronic hepatitis B. Liver Int 2009;29:242-7. 
22. Coco B, Oliveri F, Maina AM, et al. Transient elastography: a new surrogate marker of liver fibrosis influenced by major changes of transaminases. J Viral Hepat 2007;14:360-9.

23. Chan HL, Wong GL, Choi PC, et al. Alanine aminotransferase-based algorithms of liver stiffness measurement by transient elastography (Fibroscan) for liver fibrosis in chronic hepatitis B. J Viral Hepat 2009;16:36-44.

24. Sebastiani G, Vario A, Guido M, et al. Sequential algorithms combining non-invasive markers and biopsy for the assessment of liver fibrosis in chronic hepatitis B. World J Gastroenterol 2007;13:525-31.

25. Lok AS, Heathcote EJ, Hoofnagle JH. Management of hepatitis B: 2000--summary of a workshop. Gastroenterology 2001;120:1828-53.

26. Intraobserver and interobserver variations in liver biopsy interpretation in patients with chronic hepatitis C. The French METAVIR Cooperative Study Group. Hepatology 1994;20:15-20.

27. Bedossa P, Poynard T. An algorithm for the grading of activity in chronic hepatitis C. The METAVIR cooperative study group. Hepatology 1996;24:289-93.

28. Castera L, Forns X, Alberti A. Non-invasive evaluation of liver fibrosis using transient elastography. J Hepatol 2008;48:835-47.

29. Castera L, Foucher J, Bernard PH, et al. Pitfalls of liver stiffness measurement: A 5-year prospective study of 13,369 examinations. Hepatology 2010;51:828-835.

30. Hanley JA, McNeil BJ. A method of comparing the areas under receiver operating characteristic curves derived from the same cases. Radiology 1983;148:839-43.

31. Castera L, Pinzani M. Biopsy and non-invasive methods for the diagnosis of liver fibrosis: does it take two to tango? Gut 2010;59:861-6. 
32. Friedrich-Rust M, Ong MF, Martens S, et al. Performance of transient elastography for the staging of liver fibrosis: a meta-analysis. Gastroenterology 2008;134:960-74.

33. Poynard T, Morra R, Halfon P, et al. Meta-analyses of Fibrotest diagnostic value in chronic liver disease. BMC Gastroenterol 2007;7:40.

34. Shaheen AA, Myers RP. Diagnostic accuracy of the aspartate aminotransferase-to-platelet ratio index for the prediction of hepatitis C-related fibrosis: a systematic review. Hepatology 2007;46:912-21.

35. Wang JH, Changchien CS, Hung $\mathrm{CH}$, et al. FibroScan and ultrasonography in the prediction of hepatic fibrosis in patients with chronic viral hepatitis. J Gastroenterol 2009;44:439-46.

36. Oliveri F, Coco B, Ciccorossi P, et al. Liver stiffness in the hepatitis B virus carrier: a noninvasive marker of liver disease influenced by the pattern of transaminases. World $\mathbf{J}$ Gastroenterol 2008;14:6154-62.

37. Myers RP, Tainturier MH, Ratziu V, et al. Prediction of liver histological lesions with biochemical markers in patients with chronic hepatitis B. J Hepatol 2003;39:222-30.

38. Ngo Y, Benhamou Y, Thibault V, et al. An accurate definition of the status of inactive hepatitis B virus carrier by a combination of biomarkers (FibroTest-ActiTest) and viral load. PLoS One 2008;3:e2573.

39. Chang PE, Lui HF, Chau YP, et al. Prospective evaluation of transient elastography for the diagnosis of hepatic fibrosis in Asians: comparison with liver biopsy and aspartate $\underline{\text { transaminase platelet ratio index. Aliment Pharmacol Ther 2008;28:51-61. }}$

40. Castera L, Le Bail B, Roudot-Thoraval F, et al. Early detection in routine clinical practice of cirrhosis and oesophageal varices in chronic hepatitis $\mathrm{C}$ : Comparison of transient elastography (FibroScan) with standard laboratory tests and non-invasive scores. J Hepatol 2009;50:59-68. 
41. Wong GL, Wong VW, Choi PC, et al. Development of a non-invasive algorithm with transient elastography (Fibroscan) and serum test formula for advanced liver fibrosis in chronic hepatitis B. Aliment Pharmacol Ther 2010;31:1095-103.

42. Kumar M, Sarin SK, Hissar S, et al. Virologic and histologic features of chronic hepatitis B virus-infected asymptomatic patients with persistently normal ALT. Gastroenterology 2008;134:1376-84.

43. Papatheodoridis GV, Manesis EK, Manolakopoulos S, et al. Is there a meaningful serum hepatitis B virus DNA cutoff level for therapeutic decisions in hepatitis B e antigen-negative chronic hepatitis B virus infection? Hepatology 2008;48:1451-9.

44. Fung J, Lai CL, Chan SC, et al. Correlation of liver stiffness and histological features in healthy persons and in patients with occult hepatitis B, chronic active hepatitis B, or hepatitis B cirrhosis. Am J Gastroenterol 2010;105:1116-22.

45. Roulot D, Czernichow S, Le Clesiau H, et al. Liver stiffness values in apparently healthy subjects: Influence of gender and metabolic syndrome. J Hepatol 2008;48:606-613.

46. Castera L, Foucher J, Bertet J, et al. FibroScan and FibroTest to assess liver fibrosis in HCV with normal aminotransferases. Hepatology 2006;43:373-4.

47. Maimone S, Calvaruso V, Pleguezuelo M, et al. An evaluation of transient elastography in the discrimination of $\mathrm{HBeAg}$-negative disease from inactive hepatitis B carriers. J Viral Hepat 2009;16:769-74.

48. Papatheodoridis GV, Chrysanthos N, Hadziyannis E, et al. Longitudinal changes in serum HBV DNA levels and predictors of progression during the natural course of HBeAg-negative chronic hepatitis B virus infection. J Viral Hepat 2008;15:434-41. 
49. Poynard T, Munteanu M, Imbert-Bismut F, et al. Prospective Analysis of Discordant Results between Biochemical Markers and Biopsy in Patients with Chronic Hepatitis C. Clin Chem 2004;10:10.

50. Fraquelli M, Rigamonti C, Casazza G, et al. Reproducibility of transient elastography in the evaluation of liver fibrosis in patients with chronic liver disease. Gut 2007;56:968-73.

51. Arena U, Vizzutti F, Corti G, et al. Acute viral hepatitis increases liver stiffness values measured by transient elastography. Hepatology 2008;47:380-4.

52. Lucidarme D, Foucher J, Le Bail B, et al. Factors of accuracy of transient elastography (fibroscan) for the diagnosis of liver fibrosis in chronic hepatitis C. Hepatology 2009:108389. 
Castéra et al.

Table 1. Characteristics of the $329 \mathrm{HBeAg}$-negative patients at the time of fibrosis evaluation according to their status: inactive carriers and chronic active hepatitis (CHB) patients.

\begin{tabular}{|c|c|c|c|c|}
\hline & $\begin{array}{c}\text { HBeAg-negative } \\
\text { Total } \\
(n=329)\end{array}$ & $\begin{array}{l}\text { Inactive } \\
\text { carriers } \\
(n=201)\end{array}$ & $\begin{array}{c}\text { HBeAg-negative } \\
\text { CHB patients } \\
(n=128)\end{array}$ & $\mathrm{p}$ \\
\hline Gender (Male) & $62 \%$ & $54 \%$ & $76 \%$ & $<0.0001$ \\
\hline Age (yrs) & $39 \pm 14$ & $36 \pm 12$ & $44 \pm 16$ & $<0.0001$ \\
\hline BMI $\left(\mathrm{kg} / \mathrm{m}^{2}\right)$ & $24.0 \pm 3.9$ & $23.7 \pm 3.8$ & $24.4 \pm 4.1$ & NS \\
\hline ALT (IU/L) $(\mathrm{N}<50)$ & $46 \pm 70$ & $27 \pm 11$ & $75 \pm 106$ & $<0.0001$ \\
\hline AST (IU/L) $(\mathrm{N}<50)$ & $37 \pm 41$ & $27 \pm 8$ & $55 \pm 61$ & $<0.0001$ \\
\hline Platelets $\left(10^{9} / \mathrm{L}\right)$ & $227 \pm 72$ & $237 \pm 67$ & $213 \pm 79$ & 0.004 \\
\hline HBV DNA (IU/mL) & $2.7 \pm 17.110^{6}$ & $1.5 \pm 2.710^{3}$ & $7.4 \pm 27.910^{6}$ & 0.0002 \\
\hline
\end{tabular}


Table 2. Diagnostic performances of transient elastography (TE), Fibrotest (FT), and APRI in the 60 patients with a liver biopsy.

\begin{tabular}{|c|c|c|c|c|c|c|c|c|c|c|}
\hline Method & $\begin{array}{l}\text { AUROC } \\
(95 \% \mathrm{CI})\end{array}$ & Endpoint & Cut-offs & $\begin{array}{l}\mathrm{Se} \\
(\%)\end{array}$ & $\begin{array}{c}\mathrm{Sp} \\
(\%)\end{array}$ & $\begin{array}{l}\text { PPV } \\
(\%)\end{array}$ & $\begin{array}{c}\text { NPV } \\
(\%)\end{array}$ & $+\mathrm{LR}$ & $-\mathrm{LR}$ & $\begin{array}{l}\text { Correctly } \\
\text { classified }\end{array}$ \\
\hline $\mathrm{TE}$ & $0.76(0.63-0.90)$ & $\mathrm{F} \geq 2$ & $>7.1 \mathrm{kPa} *$ & 68 & 63 & 83 & 42 & 1.84 & 0.51 & $67 \%$ \\
\hline \multirow[t]{2}{*}{ APRI } & $0.66(0.50-0.82)$ & & $<0.5$ & 62 & 64 & 38 & 64 & 1.72 & 0.59 & \\
\hline & & & $\geq 1.5$ & 14 & 100 & 100 & 30 & inf & 0.86 & $27 \%$ \\
\hline $\mathrm{TE}$ & & & $>11.0 \mathrm{kPa}$ & 73 & 87 & 65 & 91 & 5.31 & 0.31 & $83 \%$ \\
\hline FT & $0.74(0.58-0.90)$ & & $>0.74$ & 47 & 91 & 67 & 84 & 5.20 & 0.58 & $80 \%$ \\
\hline \multirow[t]{2}{*}{ APRI } & $0.79(0.67-0.91)$ & & $<1.0$ & 47 & 80 & 44 & 82 & 2.35 & 0.66 & \\
\hline & & & $\geq 2.0$ & 13 & 96 & 50 & 76 & 3.25 & 0.90 & $63 \%$ \\
\hline
\end{tabular}


Table 3. Characteristics of the 11 inactive carriers patients with baseline elevated liver stiffness values $(>7.2 \mathrm{kPa})$ with repeated measurements.

\begin{tabular}{|c|c|c|c|c|c|c|c|c|c|c|c|c|c|c|c|c|c|c|c|c|}
\hline Patients & $\begin{array}{c}\text { Gender } \\
\text { lage }\end{array}$ & $\begin{array}{c}\text { BMI } \\
\left(\mathrm{kg} / \mathrm{m}^{2}\right)\end{array}$ & $\begin{array}{c}\text { ALT } \\
\text { B-line } \\
\text { (IU/L) }\end{array}$ & $\begin{array}{l}\text { HBV } \\
\text { DNA } \\
\text { B-line } \\
\text { (IU/L) }\end{array}$ & $\begin{array}{c}\text { LSM } \\
\text { B-line } \\
(\mathrm{kPa})\end{array}$ & $\begin{array}{c}\text { FT } \\
\text { B-line }\end{array}$ & $\begin{array}{l}\text { APRI } \\
\text { B-line }\end{array}$ & $\begin{array}{l}\frac{\text { Delay }}{\text { B-line }} \\
\underline{\text { \& EOF }} \\
\underline{\text { (days) }}\end{array}$ & $\frac{\underline{\mathrm{LSM}}}{\underline{2 \mathrm{nd}}} \underline{\underline{\mathrm{kPa})}}$ & $\frac{\underline{\mathrm{LSM}}}{\underline{3 \mathrm{rd}}} \frac{(\mathrm{kPa})}{\underline{\mathrm{kPa}}}$ & $\frac{\underline{\mathrm{LSM}}}{\underline{4 \mathrm{th}}}$ & $\frac{\text { FT }}{\underline{\text { 2nd }}}$ & $\underline{\mathrm{FT}}$ & $\frac{\text { FT }}{4 \text { th }}$ & $\frac{\text { APRI }}{\underline{2 n d}}$ & $\frac{\text { APRI }}{\underline{3 r d}}$ & $\frac{\text { APRI }}{\underline{4 \text { th }}}$ & $\begin{array}{c}\text { ALT } \\
\text { EOF } \\
(\mathrm{IU} / \mathrm{L})\end{array}$ & $\begin{array}{c}\text { HBV } \\
\text { DNA } \\
\text { EOF } \\
\text { (IU/L) }\end{array}$ & LB \\
\hline 1 & $\mathrm{M} / 25$ & 21.6 & 33 & 7536 & 7.4 & 0.12 & 0.24 & $\underline{460}$ & $\underline{7.3}$ & $\underline{6.5}$ & $\underline{7.8}$ & $\underline{0.09}$ & $\underline{0.16}$ & $\underline{0.20}$ & $\underline{0.17}$ & $\underline{0.23}$ & $\underline{0.23}$ & 35 & 7325 & $\mathrm{~F} 2$ \\
\hline 2 & $\mathrm{~F} / 25$ & 19.7 & 24 & $<12$ & 7.8 & 0.17 & 0.13 & $\underline{182}$ & $\underline{4.1}$ & $\underline{5.8}$ & $=$ & $\underline{0.22}$ & $\underline{0.14}$ & $=$ & $\underline{0.19}$ & $\underline{0.17}$ & $=$ & 32 & $<12$ & No \\
\hline 3 & $\mathrm{M} / 49$ & 27.1 & 35 & $<12$ & 7.8 & 0.20 & 0.24 & $\underline{179}$ & $\underline{6.8}$ & $=$ & $=$ & $\underline{0.18}$ & $=$ & $=$ & $\underline{0.26}$ & $=$ & $=$ & 35 & $<12$ & No \\
\hline 4 & $\mathrm{M} / 31$ & 20.5 & 18 & 315 & 7.9 & 0.13 & 0.25 & $\underline{253}$ & $\underline{5.9}$ & $=$ & $=$ & $\underline{0.22}$ & $=$ & $=$ & $\underline{0.32}$ & $=$ & $=$ & 23 & $<12$ & No \\
\hline 5 & $\mathrm{M} / 52$ & 23.4 & 47 & 1600 & 8.0 & 0.43 & 0.08 & $\underline{236}$ & $\underline{5.4}$ & $\underline{4.8}$ & $=$ & $\underline{0.33}$ & $\underline{0.28}$ & = & $\underline{0.10}$ & $\underline{0.09}$ & $=$ & 34 & 973 & No \\
\hline 6 & $\mathrm{M} / 18$ & 21.8 & 24 & 662 & 8.2 & 0.11 & 0.41 & $\underline{395}$ & $\underline{9.8}$ & $\underline{9.5}$ & $\underline{12.7}$ & $\underline{0.12}$ & $\underline{0.08}$ & $\underline{0.06}$ & $\underline{0.28}$ & $\underline{0.35}$ & $\underline{0.36}$ & 21 & 372 & F3 \\
\hline 7 & $\mathrm{M} / 59$ & 24.9 & 29 & $<12$ & 8.6 & 0.34 & 0.60 & $\underline{247}$ & $\underline{6.3}$ & $=$ & $=$ & $\underline{0.30}$ & $=$ & $=$ & $\underline{0.51}$ & $=$ & $=$ & 20 & $<12$ & No \\
\hline 8 & $\mathrm{M} / 22$ & 24.6 & 25 & 1782 & 8.8 & 0.16 & 0.54 & $\underline{100}$ & $\underline{5.9}$ & $=$ & $=$ & $\underline{0.15}$ & $=$ & $=$ & $\underline{0.54}$ & $=$ & $=$ & 29 & 1239 & No \\
\hline 9 & $\mathrm{M} / 45$ & 23.4 & 38 & 774 & 9.4 & 0.14 & 0.31 & $\underline{186}$ & $\underline{6.1}$ & $\underline{6.7}$ & $\underline{6.6}$ & $\underline{0.10}$ & $\underline{0.27}$ & $\underline{0.20}$ & $\underline{0.35}$ & $\underline{0.44}$ & $\underline{0.38}$ & 38 & 118 & No \\
\hline 10 & $\mathrm{M} / 23$ & 19.6 & 21 & 9380 & 9.5 & 0.06 & 0.21 & $\underline{416}$ & $\underline{6.9}$ & $\underline{6.8}$ & $=$ & $\underline{0.13}$ & $\underline{0.12}$ & $=$ & $\underline{0.17}$ & $\underline{0.20}$ & $=$ & 9 & 9216 & No \\
\hline 11 & $\mathrm{M} / 26$ & 26.4 & 40 & 566 & 11.6 & 0.41 & 0.36 & $\underline{329}$ & $\underline{5.8}$ & $\underline{5.3}$ & $\underline{4.9}$ & $\underline{0.30}$ & $\underline{0.42}$ & $\underline{0.58}$ & $\underline{0.43}$ & $\underline{0.35}$ & $\underline{0.46}$ & 42 & 715 & No \\
\hline
\end{tabular}


Table 4. Median (IQR) intra-patient liver stiffness, Fibrotest ${ }^{\circledR}$, APRI, AST, ALT and HBV DNA values changes at different time points relative to baseline in inactive carriers patients with at least 2 determinations of non invasive methods over time (End of follow-up (EOF): last determination available).

\begin{tabular}{|c|c|c|c|c|c|c|c|c|c|c|c|c|c|}
\hline Patients & $\begin{array}{l}\text { Time } \\
\text { point }\end{array}$ & $\begin{array}{l}\text { Liver stiffness } \\
\qquad(\mathrm{kPa})\end{array}$ & $\mathrm{p}$ & Fibrotest ${ }^{\circledR}$ & $\mathrm{p}$ & APRI & $\mathrm{p}$ & $\frac{\mathrm{AST}}{(\mathrm{IU} / \mathrm{L})}$ & $\mathrm{p}$ & $\underline{\underline{\mathrm{ALT}}} \underline{\underline{(\mathrm{IU} / \mathrm{L})}}$ & $\mathrm{p}$ & $\frac{\text { HBV DNA }}{\underline{(\mathrm{IU} / \mathrm{L})}}$ & $\mathrm{p}$ \\
\hline $\begin{array}{l}2 \text { time } \\
\text { points } \\
(\mathrm{n}=82)\end{array}$ & EOF & $\begin{array}{c}-0.2 \\
(-1.2-+0.7)\end{array}$ & 0.12 & $\begin{array}{c}+0.03 \\
(-0.04-+0.09)\end{array}$ & 0.012 & $\begin{array}{c}-0.01 \\
(-0.07-+0.03)\end{array}$ & $<0.05$ & $\underline{\underline{0.0}} \underline{(-4.0-+4.0)}$ & $\underline{0.99}$ & $\underline{\left(-6.0-+0^{0.0}\right.}$ & $\underline{0.64}$ & $\underline{(-461 \stackrel{0.0}{-+290)}}$ & $\underline{0.98}$ \\
\hline \multirow{2}{*}{$\begin{array}{l}3 \text { time } \\
\text { points } \\
(n=48)\end{array}$} & $2^{\text {nd }}$ & $\begin{array}{c}+0.1 \\
(-0.9-+0.5)\end{array}$ & 0.41 & $\begin{array}{c}+0.03 \\
(-0.03-+0.07)\end{array}$ & 0.03 & $\begin{array}{c}-0.02 \\
(-0.06-+0.02)\end{array}$ & 0.02 & $\begin{array}{c}\underline{0.0} \\
(-5.5-+3.0) \\
\end{array}$ & $\underline{0.28}$ & $\frac{-2.0}{(-9.0-+2.0)}$ & $\underline{0.10}$ & $\begin{array}{c}\frac{117.0}{(-509-+3230)} \\
\end{array}$ & $\underline{0.14}$ \\
\hline & $3^{\text {rd }}$ & $\begin{array}{c}-0.1 \\
(-0.9-+0.5)\end{array}$ & 0.33 & $\begin{array}{c}+0.05 \\
(-0.03-+0.11)\end{array}$ & 0.001 & $\begin{array}{c}-0.01 \\
(-0.08-+0.04)\end{array}$ & 0.41 & $\begin{array}{c}\underline{0.5} \\
\left(-3.8^{-+}+5.0\right) \\
\end{array}$ & $\underline{0.99}$ & $\begin{array}{c}\underline{0.0} \\
(-5.0-+4.0) \\
\end{array}$ & $\underline{0.80}$ & $\begin{array}{c}0.0 \\
(-770-+848) \\
\end{array}$ & $\underline{0.82}$ \\
\hline \multirow{3}{*}{$\begin{array}{l}4 \text { time } \\
\text { points } \\
(n=27)\end{array}$} & $2^{\text {nd }}$ & $\begin{array}{c}+0.2 \\
(-0.8-+0.9)\end{array}$ & 0.98 & $\begin{array}{c}0.00 \\
(-0.04-+0.06) \\
\end{array}$ & 0.55 & $\begin{array}{c}0.00 \\
(-0.06-+0.04) \\
\end{array}$ & 0.45 & $\frac{2.0}{(-4.0-+4.0)}$ & $\underline{0.60}$ & $\frac{0.0}{(-3.0-+7.0)}$ & $\underline{0.90}$ & $\frac{117.0}{(-422-+4076)}$ & $\underline{0.18}$ \\
\hline & $3^{\mathrm{rd}}$ & $\begin{array}{c}-0.1 \\
(-1.0-+0.5)\end{array}$ & 0.50 & $\begin{array}{c}+0.07 \\
(0.00-+0.13) \\
\end{array}$ & 0.002 & $\begin{array}{c}+0.02 \\
(-0.06-+0.06)\end{array}$ & 0.71 & $\frac{2.0}{(-2.0-+6.0)}$ & $\underline{0.22}$ & $\frac{2.0}{(-3.0-+7.0)}$ & $\underline{0.09}$ & $\frac{-70.0}{(-1786-+91)}$ & $\underline{0.21}$ \\
\hline & $4^{\text {th }}$ & $\begin{array}{c}+0.1 \\
(-1.1-+0.9) \\
\end{array}$ & 0.88 & $\begin{array}{c}+0.05 \\
(-0.02-+0.09)\end{array}$ & 0.08 & $\begin{array}{c}+0.01 \\
(-0.05-+0.05) \\
\end{array}$ & 0.75 & $\frac{3.0}{\left(-1.0^{\underline{3-+}+5.0)}\right.}$ & $\underline{0.07}$ & $\frac{3.0}{\left(-1.3^{\underline{3-}+9.0)}\right.}$ & $\underline{0.03}$ & $\begin{array}{c}\underline{4.0} \\
(-1806-+244) \\
\end{array}$ & $\underline{0.89}$ \\
\hline
\end{tabular}

EOF: end of follow-up; $p$ values are for intra-patients changes relative to baseline. 


\section{Legend for figures}

Figure 1. Box plots of liver stiffness (A), Fibrotest ${ }^{\circledR}$ (B), and APRI (C) values in the 201 IC patients and the $128 \mathrm{CHB}$ patients. The top and bottom of the boxes are the first and third quartiles, respectively. The length of the box thus represents the IQR within which $50 \%$ of the values were located. The line through the middle of each box represents the median. The error bars show the minimum and maximum values (range).

Figure 2. Box plots of liver stiffness (A), Fibrotest ${ }^{\circledR}$ (B), and APRI (C) values in the 201 IC patients according to HBV DNA levels. The top and bottom of the boxes are the first and third quartiles, respectively. The length of the box thus represents the IQR within which $50 \%$ of the values were located. The line through the middle of each box represents the median. The error bars show the minimum and maximum values (range).

Figure 3. Evolution over time of liver stiffness (A), Fibrotest ${ }^{\circledR}(B)$, and APRI (C) values in the 48 inactive carriers patients who underwent three determinations over time (median: 23.1 months; range: 10.1-34.7). Median intra-patient changes at different time points relative to baseline (top) and individual data (bottom). 
Figure 1

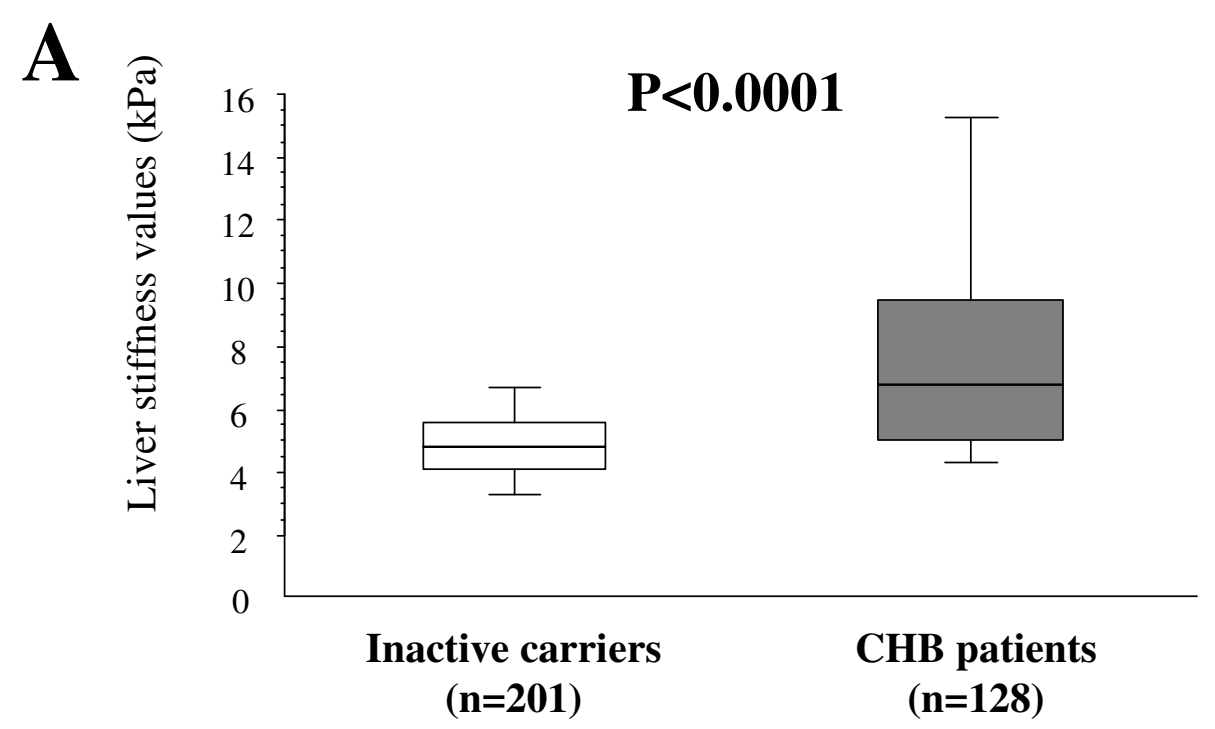

B

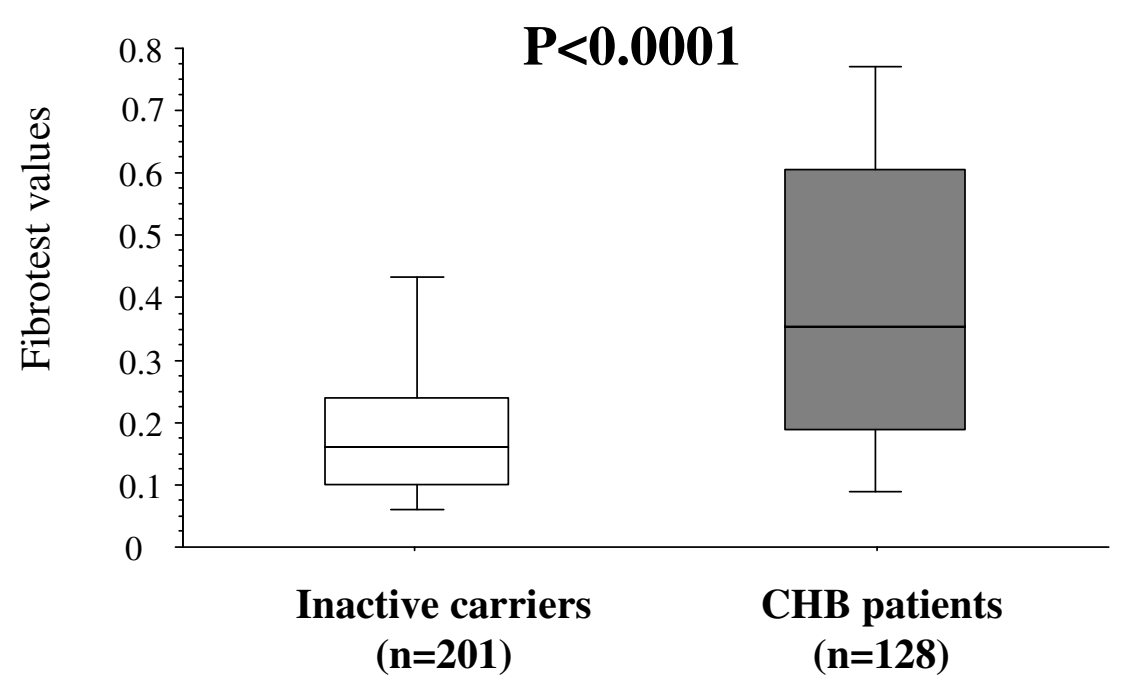

C

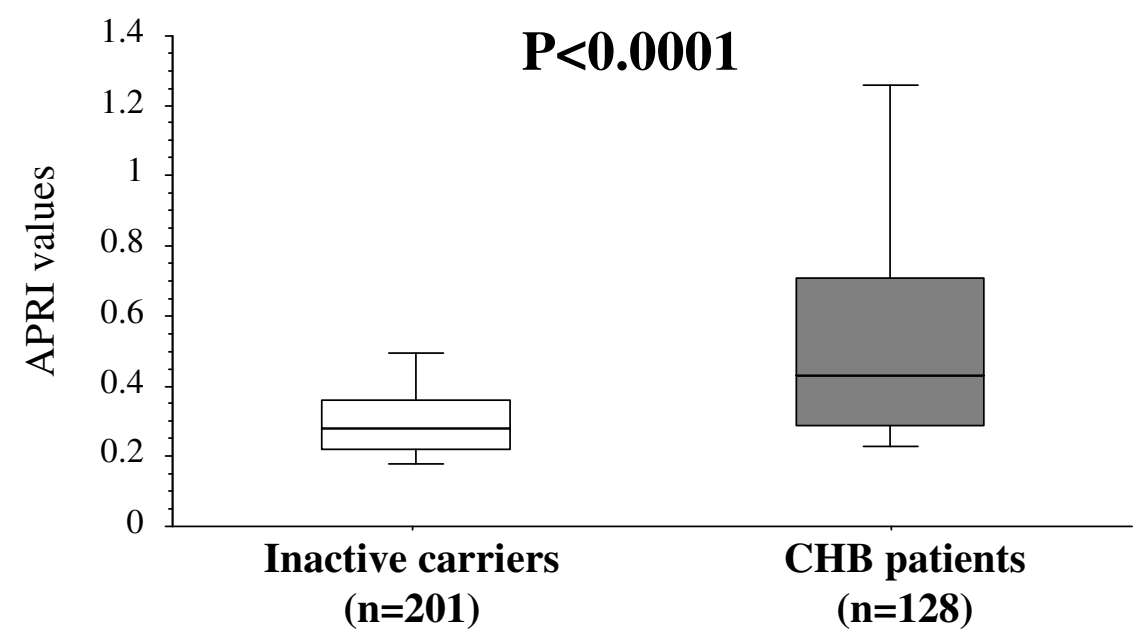


1

2

3

4

5

6

8

9

10

11

12

13

14

15

16

17

18

19

20

21

22

23

24

25

26

27

28

29

30

31

32

33

34

35

36

37

38

39

40

41

42

43

44

45

46

47

48

49

50

51

52

53

54

55

56

57

58

59

60
Figure 2

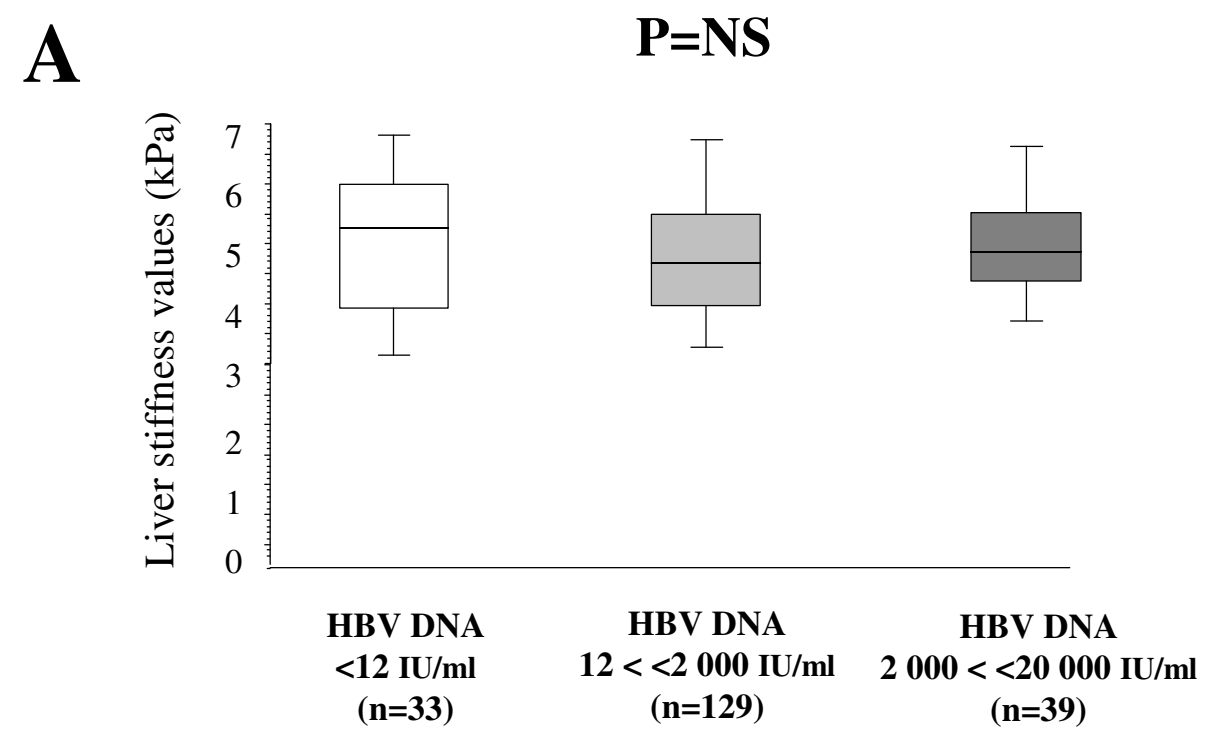

B
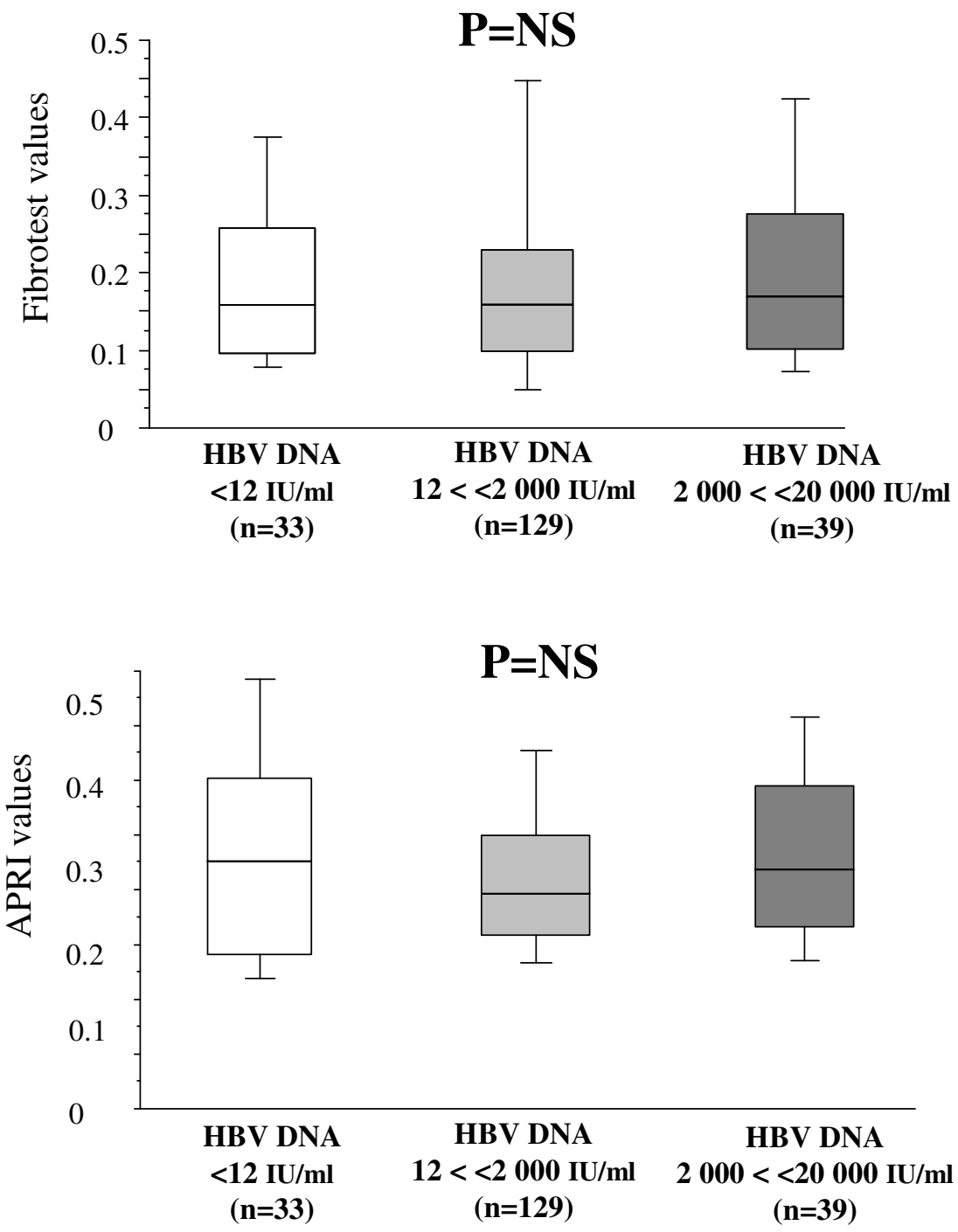


\section{Figure 3}

\section{A}
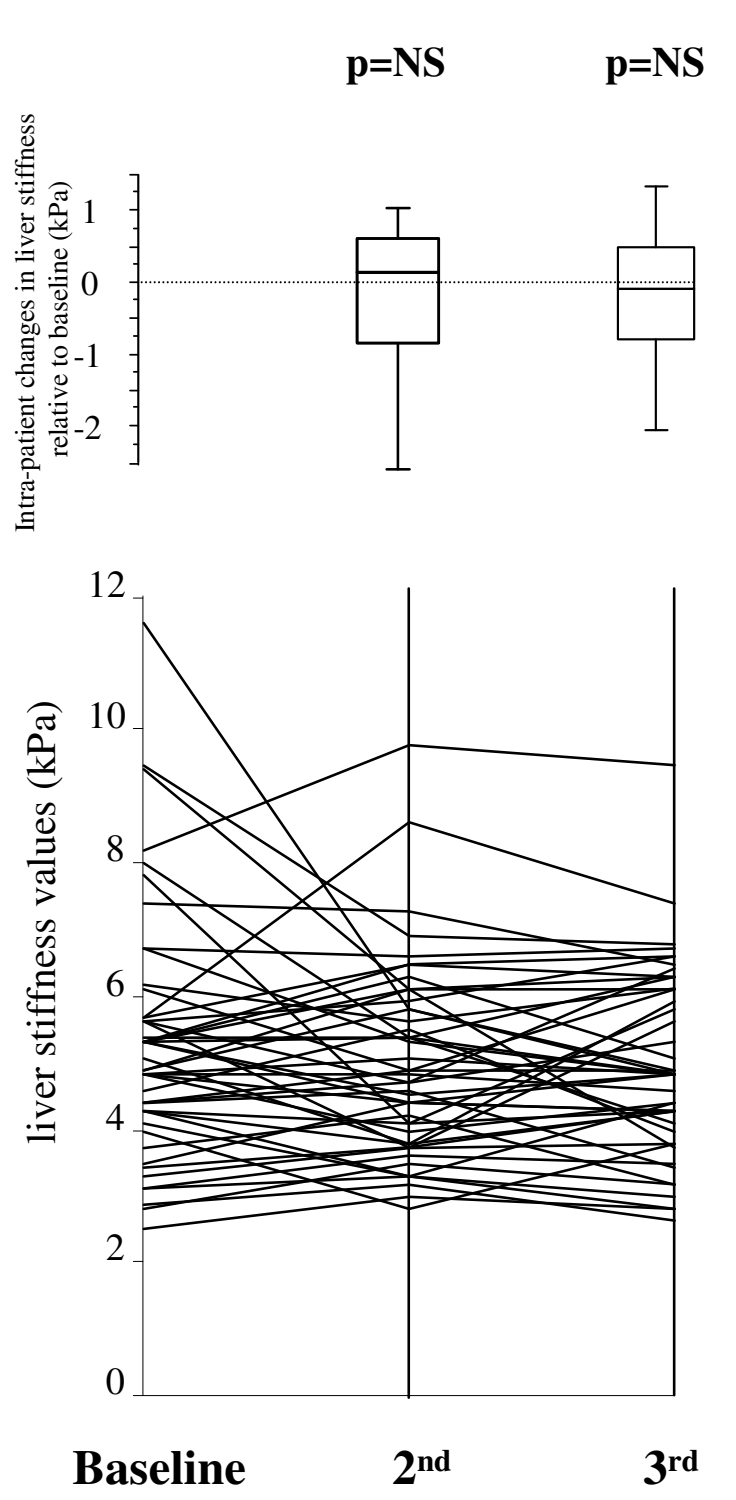

B
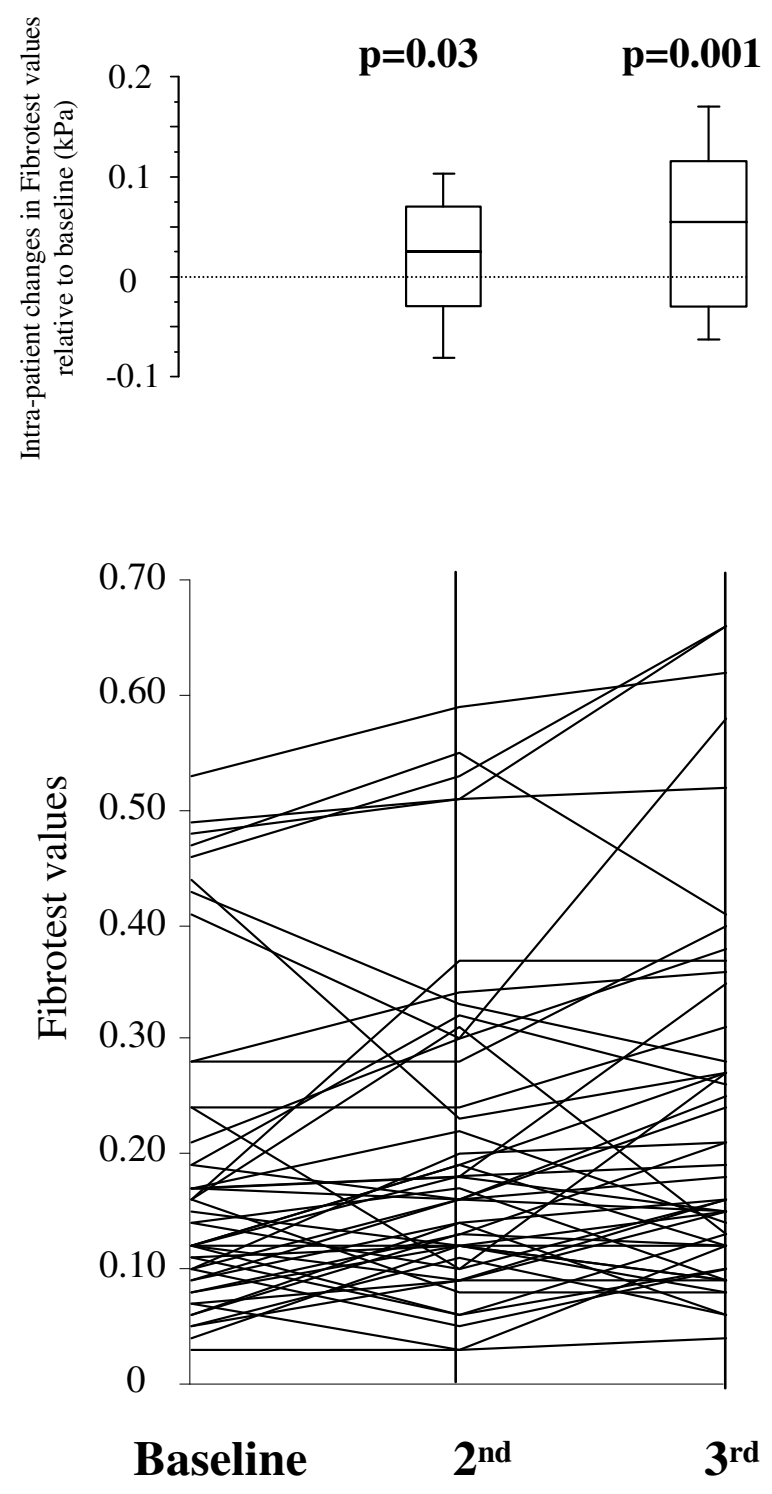
$\mathbf{p}=\mathbf{0 . 0 0 1}$
C $\mathbf{P}=0.02 \quad p=N S$
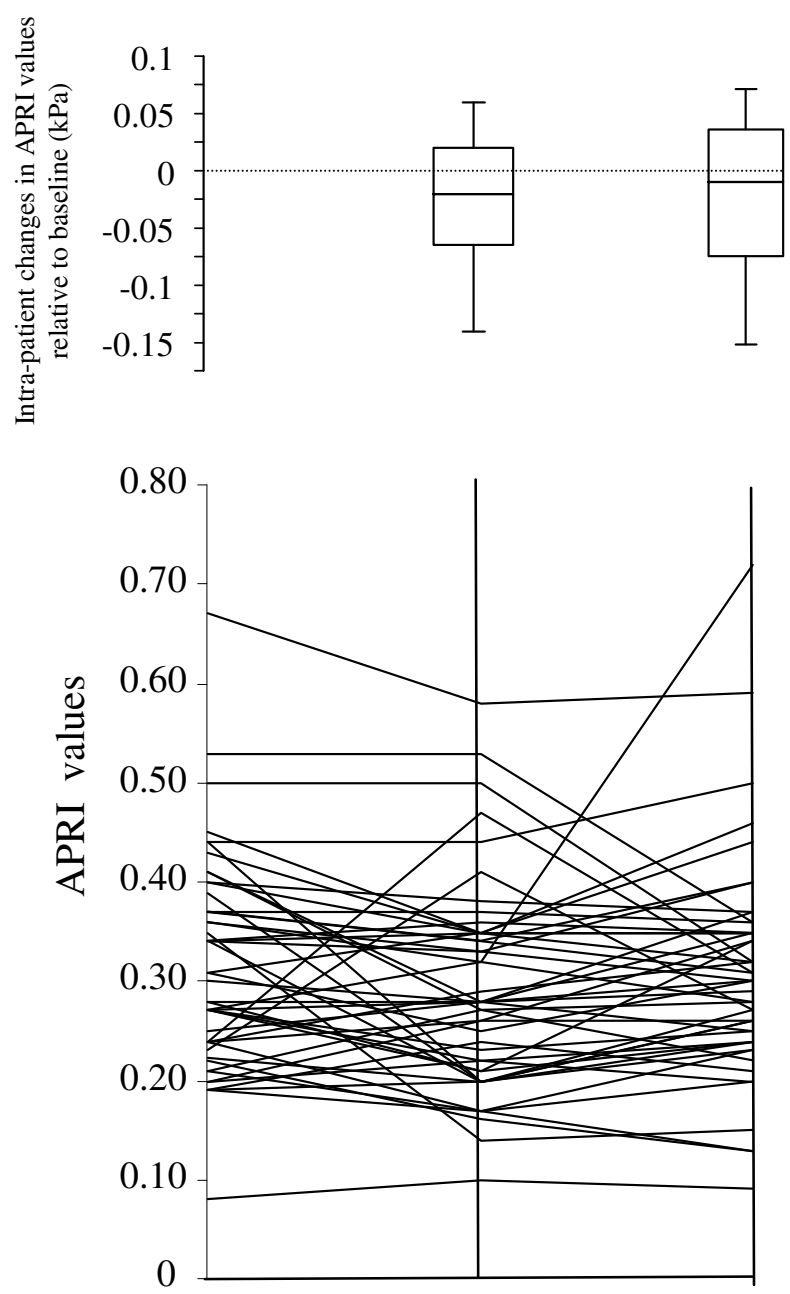

Baseline $\quad 2^{\text {nd }} \quad 3^{\text {rd }}$ 